\title{
STUDY OF THE BOKA (TREASURY) ADAT MARRIAGE OF THE CIA-CIA BUTON IN THE KALAULI HAMLET OF THE HILA-KAITETU DISTRICT, LEIHITU DISTRICT, CENTRAL MALUKU REGENCY.
}

\author{
Wa Ima* and Samuel M. Wattimury \\ Department of Education, Faculty of Teacher Training and Education, \\ Pattimura University Ambon. \\ *email: ima@yahoo.co.id
}

\begin{abstract}
Background in research in the Kalauli Negeri Hila-Kaitetu sub-district Leihitu, Central Maluku Regency, there are various tribes including indigenous people, Butonese, Bugis, Makassarese, and other tribes. In social life, where the Buton tribes live side by side and foster good relations of kinship and kinship between the indigenous people and with other tribes. Customs that are still preserved and preserved by the Buton tribe in Maluku, especially in Central Maluku, precisely in the Kalauli Hamlet, in this case the marriage custom. Customary marriages are part of customary Buton tribes that use customary forms of marriage can have good aspects related to the system of norms, rules and values that apply to Buton tribes in the Kalauli subvillage. So that after all the conditions of the customary marriage is maintained by the community supporters, especially the customary marriage of the Buton tribe. In the life of the Buton Cia-cia tribe in the Kalauli Negeri Hila-Kaitetu Hamlet, Leihitu District, Central Maluku Regency, in marriages there are various stages of marital custom that are still maintained, among others, namely the Boka custom (treasure money). which must be submitted from the prospective male bride to the bride-to-be. The purpose of this research is: to find out the traditional traditions of the Boka (Cone-Cia) Buton tribe marriage in Kalauli Negeri Hila-Kaitetu Hamlet, Leihitu District, Central Maluku Regency ". Methodology, based on the problems and objectives to be achieved, the type of research used is descriptive research with a cultural approach. The research results show that the customary marriage of the Buton Cia-Cia tribe in the Kalauli hamlet of the State of Hila-Kaitetu in the District of Leihitu, Central Maluku Regency "in the form of a Boka custom or treasure money, which always develops over time, as well as the values contained in the Boka marriage or money property, is the value of mutual cooperation, religion, tolerance, and siltuhrahmi.
\end{abstract}

Keywords: Traditional Marriage, Cia-cia Buton Tribe.

\section{Introduction}

Humans as God's creatures are the most perfect among other creatures, have high human dignity and so have the instinct to live in pairs. In fostering shared relations, of course there are many custom series that must be carried out because Adat comes from the words "a" and "dato" in Sangsekerta "a" which means not and "dato" which leads to material (Soejono Soekanto 2010: 70). Meanwhile, according to the marriage law in force in Indonesia article 1, marriage is an inner birth bond between a man and a woman as husband and wife with the aim of forming a happy and eternal family (household) based on the Godhead of the Almighty (Amir Syarifudin 2007:40).

Customary marriages are part of the customary tribes of the Butonese who use traditional forms of marriage can have good aspects related to the norm system that applies to the Butonese community in the Kalauli sub-village. So that after all the conditions of the customary marriage is maintained by the community supporters, especially the customary marriage of the Buton tribe. In the life of the Buton Cia-Cia tribe in Kalauli Hamlet, Leihitu District, Central Maluku Regency, in marriage there are various customs that are still preserved, namely the Boka custom / treasure money. The Boka custom / money is customary in the marriage of the Buton Cia-cia tribe in the

Received April 28 $8^{\text {th }} 2020$, Revision May $31^{\text {st }} 2020$, Accepted for publication June $18^{\text {th }} 2020$.

Copyright @ 2020 Published by FKIP - Unpatti, ISSN 2721-3110 
Kalauli hamlet in the form of money, which must be handed over from the prospective bridegroom to the prospective bride to be married, from some Buton tribes who are required to carry out this customary process, most of the community no longer know it. In the Kalauli hamlet community, the custom of marriage is still maintained by the Buton Cia-Cia tribe untilnow.

The Concept of Culture The word "culture" comes from the Sangsekerta language buddhayah, the plural of buddhi which means "mind" or "reason". Thus, culture can be interpreted "things concerned with reason". When you see the basic word, the word "culture" is a compound development of "cultivation" which means "the power of mind". From this understanding then differentiated between culture which means "the power of mind", in the form of creativity, intention and intention with culture which means the results of copyright, intention, and taste. (P. Hariyono, 1996: 44).

According to Deddy Mulyana and Jalaludin Rakmhat (2010: 18) culture is a concept that arouses interest. Formally culture is defined as the order of knowledge, experience, beliefs, values, attitudes, meanings, hierarchies, religions, time, roles, space relations, concepts of the universe, material objects and possessions that are obtained by a large group of people from generation to generation through effort individuals and groups. From the explanation above then M. M. Djojodigeono in P. Hariyono (1996: 45) said that culture is "the power of mind in the form of creativity, intention and taste".

The learning process of this cultural system is carried out through acculturation or institutionalization. In this institutionalization process, individuals learn and preserve the nature of their minds and attitudes with customs, norms, regulations, which live in culture. Institutionalization began in childhood (even humans are still in the womb), in the family environment, the environment outside the home and the wider community. Each environment has its own system peculiarities so that every individual who wants to enter the environment must go through civilization (institutionalization).

From the understanding of culture according to the experts above, the author concludes that culture is everything created by humans, whether in the form of creativity, taste, and intention, which grows and develops according to the needs of the times.

Definition of Custom Adat is a rule that is often carried out by people continuously, custom is usually a legacy inherited from generation to generation within a community. Etymologically indigenous comes from the Arabic word adha which means habit. So custom can also be defined as a habit that is continuously carried out, and repeatedly so that it becomes a habit. Meanwhile, Rajo Panghulu in (Soejono Soekanto 2010: 70) said that adat means immaterial nature: that is, adat involves matters relating to belief systems. From the above opinion it can be concluded that adat is a habit carried out by ancestors which is continuously passed on from one generation to another Buton tribe In the general Indonesian dictionary written by J. S. Badudu and Sultan Mohammad Zain (1994: 13) tribal, in groups, in tribes, bound by groups according to their tribes. While the word Buton is a word used by Belada people to refer to the area under the government of the Buton kingdom, while the original word is Butun which is used for the mention of the imperial area. Mention of it Butun is often used by sailors in the archipelago who often come to the island. Because of the large number of Butu trees (Barringtonia Asiatica) there, the sailors called Butun a marker of the island. So the mention of Butun had existed before the Majapahit people inscribed the name Butun in Nagarakartagama (1365) within the framework of the tribute payment area, the naming of Butun was already used by the local community of the area (Susanto Zuhdi 2010: 1). It can be concluded that the Butonese are a group of people related to the awareness and identity of cultural unity derived from the identity of their tribe or group of people who live in a community. In this case the Butonese originated from the island of Southeast Sulawesi or the region of Southeast Sulawesi. 
Definition of Marriage It has become natural nature, since birth humans always live together with other humans in a social life. Living together with humans is to meet their needs, both physical and spiritual. Living together between a man and a woman who have fulfilled the requirements certain conditions, called marriage. Marriage according to religion sacred ties between a female guardian (future wife) with a prospective female husband is not an engagement between a man and a woman alone. That matter shows that marriage ties in Islam also means kinship rather than individual ties. In the Koran it is emphasized that the purpose of marriage is to create a family that is sakinah (peaceful), mawaddah (full of love), and rahmah (full of respect) among family members, namely husband, wife and children. Allah SWT. said: "And among the signs of His power is that $\mathrm{He}$ created for you wives of your own kind, so that you are inclined and feel at ease with him, and made Him among you a feeling of love and affection. Verily in that are indeed signs for people who think "(QS. Al-Rum [30]: 21).

Thus marriage is an inner-birth bond of two people of different sexes to form a harmonious, prosperous family and to remember the two big families with different backgrounds become a unified whole. Understanding Customary Marriage What is meant by customary marriage is all customs, habits that are usually done in a community to regulate issues related to marriage (Supomo, in Pethein Mantouw Thesis 2014: 14). In human life, almost all indigenous communities have marital problems as a matter of family and other relatives, both men and women who have a function to enable community growth. Customary ceremony is a trajectory in a community that must be carried out as the antidote to the dangers that exist, as has been said above, marriage is a cultural element that is lived from time to time in which contains very strong values and norms, regulating and directing the behavior of each individual in one society.Customary marriage for the Buton Cia-cia tribe is a very sacred thing and must be done because it affects the survival of the bride and groom. With adat marriage can also determine the level of a person's status. Customary marriages are increasingly developing along with the times and must be kept, maintained and preserved.

Based on the background description above, the authors deem it necessary to conduct research with the title. "The study of the Boka marriage customs or the money of the Cia-Cia Buton tribe in the Kalauli hamlet, Hila Kaitetu, Leihitu District, Central Maluku Regency". Formulation of the problem Based on the above background, the problem of this research can be formulated as follows: How is the Boka marriage customary or the wealth of the Cia-Cia Buton tribe in the Kalauli Negeri Hamlet Hila Kaitetu, Leihitu District, Central Maluku Regency? The objectives in this study were: to showed that Boka marriage customs or the money of the Buton Cia-cia tribe in the Kalauli hamlet Negeri Hila Kaitetu, Leihitu District, Central Maluku Regency, and to find out the values contained in the Boka marriage tradition or treasure money in the Cia-cia Buton tribe in the Kalauli Negeri Hamlet, Hila Kaitetu, Leihitu District, Central Maluku Regency.

\section{Research Methods}

This type of research is descriptive qualitative research that is research that produces descriptive data, in the form of written or oral words from people with behaviors that can be observed (Lexy J. Moleong, 2000: 3) and by using a cultural approach that aims to find out about the traditional tradition of marriage of the Buton Cia-Cia Tribe. This research was conducted in the hamlet of Kalauli Negeri Hila-Kaitetu, Leihitu District, Central Maluku Regency. The sources of data in this study are traditional figures, religious leaders, and the community who are considered important and know the problems studied, data collection techniques used are literature, observation, interview.

Data analysis techniques using data triangulation data are: data, theory and methodology, after that the classification process of selection and simplification of rough data is 
available in the field notes as well as discarding things that are considered not important and organizing the data in such a way as to be accurate and then draw conclusions. To end the process, the final step in the data analysis process is to present the results of scientific research (Lexy J. Moleong, 2000: 10). To guarantee the validity of the data or the validity of the data, the various data obtained are always matched or compared first with the same data from different sources using data triangulation (Lexy J. Moleong, 2000: 178).

\section{Results and Discussion}

A pair of lovers who have had a dating relationship on the basis of love and love at a mature age and have been able to be spiritually and physically certainly they already have a solid aspiration to unite their love relationship that is the sacred level of the marriage level. Marriage is a legal, physical and spiritual bond that can not separate the lovers. because marriage is the end of courtship and marriage is the beginning of a new household life to continue the new ideals in harmony, fate and continuity in running the household whether difficult or happy they always face together with confidence.

Before the marriage was carried out, of course, going through various continuous processes based on the customs of each region, such as the Butonese Cia-Cia tribe in the Kalauli Hamlet. The process starts from the proposal or proposal until the wedding ceremony is held. So in this research that will be discussed is the Boka custom / treasure money. The Boka custom or treasure money is generally divided into 3 types, i.e. Custom Boka / customary money Boka is customary property that must be paid by the prospective husband to the bride to be married based on customary provisions or mutual agreement with the family of the woman. Boka or traditional assets that must be paid in the Buton Cia-Cia community in the Kalauli sub-village are also different because they are seen based on caste groups. High caste groups such as the nobility or descendants of the king surnamed Ode (Kaimudin) and the caste group of ordinary people or ordinary people. The value of each boka consists of Rp. 24000. The division of the number of boka referred to is as follows: The caste group with Ode surname with the number of boka to be paid is 95 boka now equal to Rp.2,280,000 while those with the surname Rumbia (maradika) number of boka to be paid in the amount of 45 boka is now equivalent to $\mathrm{Rp} 1,080,000$. The number of boka is adjusted to the number of dollars that continues to increase. For ordinary people, there are 25 boka in the amount of Rp. 1,000,000, - the amount of boka is paid according to the results of a joint discussion from both parties. In general, Boka custom or treasure money consists of 4 types, namely:

a. Boka Sara (Adat Management) which contains a betel place in which there are 5 betel leaves, 5 betel nuts, 5 gambier pieces, 5 bunches of lime with the money agreed upon by both parties. Usually the value of money is calculated based on the number of boka. For boka sara (traditional management usually consists of 5 boka. 1 boka valued at Rp. 24,000, so that the total boka for Boka Sara (Adat Management) is Rp: 120,000 . This rupiah value is not an absolute price depending on the agreement or the results of deliberations from both parties so that the amount of boka can go up or down depending on mutual agreement.The meaning of number 5 shows that the village of Kalauli was included in Patalima.

b. Boka Hukumu (caretaker of the mosque). Boka Hukumu (caretaker of the mosque) consists of a betel place containing 17 areca nuts, 17 bundles of betel leaves, 17 pieces of gambier, and 17 bunches of lime. With the amount of money agreed by both parties. Usually the value of money is calculated based on the number of boka. For Boka Hukumu (mosque management) usually consists of 17 boka. So that the total boka that must be submitted by men is $\mathrm{Rp} .408,000$. This rupiah value is not an absolute price depending on the agreement or the results of deliberations from both parties so that the amount of the boka can go up or down depending on the mutual

Received April $28^{\text {th }} 2020$, Revision May $31^{\text {st }} 2020$, Accepted for publication June $18^{\text {th }} 2020$. 
agreement. The meaning of number 17 shows that in Islamic teachings the total number of fard prayers or prayer must amount to 17 cycles so that the management of the Kalauli hamlet mosque set the number of boka amounted to 17.

c. Boka toba po'elea, (Women's family). Boka toba po'elea, (Women's family) consists of a betel container containing 7 betel nuts, 7 bundles of betel leaves, 7 pieces of gambier, and 7 bundles of lime. With the amount of money agreed by both parties. Usually the value of money is calculated based on the number of boka. For Boka toba po'elea, (Women's family) usually consists of 22.5 boka. So that the total boka that must be submitted by men is Rp. 540,000. This rupiah value is not an absolute price depending on the agreement or the results of deliberations from both parties so that the amount of the boka can go up or down depending on the mutual agreement.

d. Boka toba Anan'too, (female self). Boka Toba Anan'too (female self) consists of a betel container containing 1 betel nut, 1 bundle of betel leaves, 1 piece of gambier, and 1 bundle of lime. With the amount of money agreed by both parties. Usually the value of money is calculated based on the number of boka. For Boka toba Anan'too, (female self) usually consists of 66 boka. So that the total boka that must be submitted by men is Rp. 1,584,000. This rupiah value is not an absolute price depending on the agreement or the results of deliberations from both parties so that the amount of the boka can go up or down depending on the mutual agreement. Boka toba Anan'too, (female self) used for buy Women's equipment from head to toe (mukena, hijab, hair clips and ties, combs, clothes, pants, sarong, cosmetics such as handbodies, lipsticks, talcum powder and sandals and shoes) and other furniture accessories such as place supplies sleep for example mats, pillows and couches or beds. Along with the times, especially women's equipment from the tip of her hair to her feet and the furniture underneath has changed but does not eliminate the existing customary provisions. The first example of bedding equipment below is a mat, but as time goes by the mat was added or replaced with a sprinted.

The things that are carried out before the marriage contract or marriage are: 1). Tahlillan. Tahlilan held the night before tomorrow the marriage will be held. The goal is to ask for guidance, fortune, smoothness and salvation of the world and the hereafter to Allah SWT so that the household is well-woven and harmonious. 2). Posuko (Penyarungan). Penyarungan (Posuko) is held on the wedding day before the consent granted Kabul (marriage contract). This posuko or sheath is carried out when greetings and rhymes from families who are representatives of the groom are answered, after that the family who escorted him was invited into the bride's house while the other bride remained standing at the door to carry out the posuko procession. One woman who is a representative of the bride and is from her mother's lineage who knows and understands the posuko custom will wash the groom's feet into the container provided where the foot first enters the container, the right foot comes first to be washed later new left leg, after that the bridegroom will be sheathed cloth that has been prepared by the bride and her family, after that the bridegroom is allowed to enter the bride's house. The procession posuko (sheath) has the meaning that the men are ready to get married and form a strong family bond and have entered into the family bond of the bride, while the meaning of the washing of the bridegroom's feet that before saying consent granted must be clean from all kinds of dirt and leave bad attitudes or actions that have been done before marriage or when single so that the marriage will remain harmonious. 
3). Consent granted (Marriage) Kabul consent is the essence of a marriage that is carried out in a community wedding in the Kalauli hamlet based on Islamic law or law. The consent of the Kabul is a sacred promise made by the bridegroom in front of many people, including families from both sides, carried out according to religion Islam. Saying the consent granted is marked that the lovers have legally become husband and wife and this is the beginning of the journey of their new household. Before the consent granted, the bride and groom will be escorted to the house of the bride and groom accompanied by religious music and songs. Arriving at the bride's house representatives from the bridegroom's family will greet religious leaders, traditional leaders and families from both parties who are in the bride's house. Then his greetings were answered by everyone who was watching the wedding. Before entering into the bride's house the representative of the bridegroom's family who escorted him would give a greeting and Islamic recitation at the door and then the greeting would be answered by all who listened and watched the wedding as intended by the families of both parties while the rhyme would be returned by the father of the priest alone. The poem starts from the representative of the party who delivers the bridegroom with the following rhyme sound: Assalamualaikum iyangi Ali, Sire Ali, where is the religion of Fatimah Jufrah Fatimah Yarasulullah. His greetings were answered by all the people who listened to his greetings and the priest representing the family of women answered rhymes with the sound of waalaikumsalamyyyli Ali, sire Ali, entered the Fatimah Jufrah religion here. The purpose of the poem is the question of the male family about where the bride is, and the priest is the representative the family of the woman tells us where the bride is. The greetings and rhymes are marked with men and their families are allowed to enter the place that has been provided by female family members, where there are already religious leaders, traditional leaders, community leaders and families of both parties with the aim of making the Kabul consent granted. washed his feet and posuko (netting). 4). Posambu (bribery). Posambu is performed by a married couple in a room witnessed by the father of the priest and the family of the bride and groom. The meaning of this signpost or bribery is that when their household is formed the bride and groom are ready to face the challenges that will occur both difficult and happy to be passed together and a wife must submit and be ready to serve her husband in all matters and vice versa. 5). Kahadari (advice). Kahadari was discussed in front of all the audience who witnessed the wedding after the consent granted. The core of that awareness is as a husband and wife must love each other, respect each other, respect, protect, if there is a problem must be resolved immediately along with good deliberation and whatever happens with various obstacles must be faced together in order to create a harmonious family or family that is harmonious sakinah (calm, serenity, safe / peaceful), mawaddah (full of love), warohmah (forgiveness, mercy, sustenance and gifts / processes and patience of husband and wife in fostering their household, as well as through sacrifice and soul force). If the awareness is violated if there is a problem, either the husband or wife run away at the parents' house, family and friends without mutual consultation, just go away and do not want to hear good advice, even if it is the parents and family, until their household falls apart until divorce occurs., then the wife or husband who goes with the problem will pay customary fines multiplied according to the demands of family fines based on the number of boka paid at the time of marriage.

The values contained in the Boka custom or money treasure Values contained in the boka marriage or treasure money include:

- Value of Deliberation, both parties of men and women in the determination of adat boka or money is determined based on the results of consensus agreement so that both parties do not feel burdened.

- Value of mutual cooperation, where in determining the boka or family assets of the family, men can work hand in hand, giving aid money voluntarily. 
- Mutual Value where men and women always work together if there is debt in the marriage process, then both parties pay it off together.

- The value of honesty in the process of determining boka adat or men's money is truly honest in expressing their ability to pay boka customs or money if the dishonest then men will feel burdened with the amount of adat boka / treasure money requested from the woman's side.

\section{Conclusions}

From the above explanation it can be concluded that the customary marriage of the Buton Cia-cia tribe in the Kalauli hamlet of the Hila-Kaitetu country of Leihitu District is still carried out following developments in the millennial generation but still preserves the customs and culture that were passed down from the previous oyang-oyang a slight cultural modification but did not eliminate the religious value contained in the traditional ceremonies carried out. So it can be concluded that preserving tradition and identity does not mean backward or primitive, but rather building an awareness to continue to understand customs and culture. Interaction with the outside community and also greatly contributes in the process of forming a transitional state from an old to modern order, because culture is a wealth of Indonesia that must be guarded, developed and preserved together.

\section{References}

Badudu, S, J. Zain, Muhammad, Sutan.1994. Indonesian General Dictionary. Jakarta: Sinar Harapan Library.

Jugiyanto, HM. 2008. Information Systems Research Methodology. Yogyakarta: CV Andi Offset.

Hariyono, P. 1996. Contextual Understanding of Basic Cultural Sciences. Yogyakarta: Canisius.

Koentjaraningrat. 1986. Introduction to Anthropology. Jakarta: New Script Publisher. Mantouw Pithein. 2014. Running Kaweng As part of the culture of the community of Kaibobo Country, West Seram District, West Seram Regency.

Moleong J. Lexy. 2000. Qualitative Research Methodology. Bandung: PT Remaja Rosdakarya.

Mulyana, Deddy. Rachmat, Jalaludin. 2010. Intercultural Communication. Bandung: PT Remaja Rosdakarya.

Nawawi, H. Hadari and Hadari, Martini, 1995. Research Instruments in the Social Field. Yogyakarta: Gajah Mada University Press.

Soekanto, Soerjono. 1942. Indonesian Customary Law. Jakarta: PT Raja Grafindo Persada.

Sugiyono 2011. Quantitative, Qualitative, and R\&D Research Methods. Bandung: Afabeta.

Syarifudin Amir. 2007. Islamic Marriage Law in Indonesia. Jakarta: Kencana

Usman, Husaini and Akbar, S. Purnomo.2003. Social Research Methodology. Jakarta: PT Bumi Aksara.

Zuhdi Susanto. 2010. History of Buton Neglected by Laburope Labuana. Jakarta: Rajawali Press 